DOI 10.18551/rjoas.2021-05.01

\title{
THE IMPACT OF THE COVID-19 PANDEMIC ON THE ECONOMY IN NORTH KALIMANTAN PROVINCE, INDONESIA
}

\author{
Didi Adriansyah*, Adymas Putro Utomo, Siti Aisyah, Ratna Dwi Christiyanti, Sholehah, \\ Enny Harvianti \\ University of Kaltara, North Kalimantan, Indonesia \\ E-mail: didibareo78@gmail.com
}

\begin{abstract}
The purpose of this study is to determine the impact of the Covid-19 pandemic on economic growth and to determine the state of the economy and health in North Kalimantan Province, as well as to find out which sectors are most affected. The method used in this research is descriptive statistical analysis, while to measure the health condition of the economy in North Kalimantan Province, 2 (two) indicators are used, namely the Effective reproduction rate (Rt) and the rate of economic growth which are grouped into 4 quadrants, meanwhile to measure the affected sector, Fuzzy C-Means is used. The results show that the economic growth of North Kalimantan Province in the second quarter experienced a contraction of up to $-3.14 \%$ but in the third quarter it got better even though it still grew minus at $-1.46 \%$. The state of the economy of North Kalimantan Province in the second quarter of 2020 is based on calculations with the indicator of the effective reproduction rate $(R t)$ and the economic growth rate of North Kalimantan Province is in the fourth quadrant which means that the number of positive cases of Covid-19 is still low but the economy is also low due to the spread of Covid19 prevention policies, namely PSBB. Whereas in the third quarter of 2020, North Kalimantan Province is in the first quadrant, which means that economic growth is still below the average economic growth in Kalimantan, but the effective reproduction rate (Rt) has increased, which is due to the relaxation of the government. From the results of the research it is also known that there are 3 (three) business sectors / fields that are categorized as highly impacted sectors, namely mining and excavation, transportation and warehousing as well as providers of accommodation, food and drink.
\end{abstract}

\section{KEY WORDS}

Covid-19 Pandemic, regional economy, Fuzzy C-Means.

Corona virus, or commonly referred to as Covid-19, first appeared in Wuhan, China and spread globally to various countries in the world. Until now, based on data from the World Health Organization (WHO) as of January 30, 2021, there were 102,554,468 confirmed cases worldwide and 2,213,594 died (WHO, 2021). Meanwhile, at the same time in Indonesia there were 1,066,313 confirmed cases of Covid-19, 862,502 recovered and 29,729 died (Satgas Penanganan Covid-19, 2021).

The impact of the spread of Covid-19 has caused many countries to take steps to limit the spread through various policies such as social restrictions, closing educational institutions, limiting mobility, to lockdown. Globally, the spread of Covid-19 does not only have an impact on health but also has an impact on disruption of production, export-import, transportation, accommodation, tourism, education which lead to poverty (Kumar et al., 2021; LUO et al., 2020; Škare et al., 2021). Businesses are required to close or reduce activities, meanwhile, according to Akbulaev et al., (2020), millions of people have lost their jobs due to the Covid-19 pandemic. The experience of the crisis due to the spread of the virus proves that the increase in positive cases causes high levels of losses to various sectors, including the economic sector, which is also mainly due to individual prevention activities and government transmission control policies (Brahmbhatt \& Dutta, 2008).

The impact in Indonesia is also not much different, such as the decline in share prices, the dispersion of the rupiah exchange rate against the US dollar (USSD), the decrease in manufacturing activities so that many workers experience layoffs, and these things then 
cause a decline in economic development. Finance Minister Sri Mulyani stated that the crisis caused by the Covid-19 virus is more complex than the crises in 1997-1998 and 2008-2009 (Putra, 2020).

The Indonesian government itself issued a policy known as Large-Scale Social Restrictions (PSBB) and has been implemented in various regions in Indonesia through Government Regulation Number 21 of 2020 concerning Large-Scale Social Restrictions in the Context of Corona Virus Disease 2019 (Covid-19) Handling Acceleration. The implementation of the PSBB is based on several laws which aim to protect the safety of the community from disasters and also the epidemic or pandemic currently occurring in Indonesia.

Meanwhile, in North Kalimantan, based on data from the North Kalimantan Province Covid-19 Task Force as of December 6, 2020, there were 1840 confirmed cases of Covid19, 22 cases died and 1150 recovered. Of course, the spread of Covid-19 which was followed by various local government policies had an impact on reducing the level of demand and supply. As stated by Damuri \& Hirawan, (2020), the economic impact caused by Covid19 depends on how massive it is, how many people are infected and what the death rate is, and how long (duration) the virus has spread. Meanwhile, according to Sakri, (2020), the severity of the impact of Covid-19 on the provincial economy is determined by 4 (four) factors simultaneously, namely: the level of the Covid-19 pandemic in the province; risk factors of natural disasters; characteristic factors of economic problems; and fiscal load factors.

From the description above, the main proposition related to this study is the global economic downturn caused by the massive spread of Covid-19. Therefore, regionally it is also necessary to investigate the impact of the spread of Covid-19 on the economy in North Kalimantan Province so that the local governments can take steps or policies in order to overcome the impact of the spread of Covid-19. The purpose of this research is to determine the impact of the Covid-19 pandemic on economic growth and to determine the state of the economy and health in North Kalimantan Province, as well as to find out which sectors are most affected.

\section{LITERATURE REVIEW}

Studies on the Covid-19 pandemic are currently being conducted by many researchers, both globally and nationally. The research themes are quite diverse, starting from the impact of the Covid-19 pandemic on the socio-economy and also on the environment. The following describes several related studies that have been carried out previously: Akbulaev et al., (2020) examine the impact of the Covid-19 pandemic on the economy and find that the result of Covid-19 decreases production and subsequently increases unemployment. (Keogh-Brown et al., 2020) using the Computable General Equelibrium (CGE) method also show that Covid-19 has the potential to incur unprecedented economic costs to the UK economy, thus requiring economic stimulus by the government and public support in preventing the spread of Covid-19. Meanwhile, Shrestha et al., (2020) using the technique for order of preference by similarity to ideal solution (TOPSIS) to determine the order of preference based on similarity with the ideal solution and calculate the pandemic vulnerability index (PVI) by making a quantitative measure of global health potential, the calculation results show that the pandemic has provided unprecedented burdens on the world economy, health, travel, event cancellations, labor, food chains, and education fields. In line with that, the research results of Škare et al., (2021) also show that Covid-19 has a negative impact on the world tourism and travel industry. The research result of Sikder, Zhang, \& Ahmod, (2020) also reinforces that the Covid-19 pandemic has resulted in a global economic crisis where there has been a recession, a collapse in the stock market, a decline in investment, a decline in currency. Therefore, the international cooperation in the fields of economy and health is recommended.

Meanwhile, the studies on the impact of the Covid-91 pandemic on agriculture have also been carried out by several researchers including (LIN \& ZHANG, 2020) where researchers investigate the impact of COVID-19 on agriculture in China using company 
survey data in Fujian-China find that although the average agricultural business experiences a decline in exports such as mushrooms and other horticultural products, the export of several agricultural products, especially grain and oil remains strong and even increases, implying that the demand for staple foods during the pandemic is likely to increase. Besides that, the export of herbal medicine also increases sharply during the pandemic. Meanwhile, MIN et al., (2020) conduct a study on the impact of the COVID-19 pandemic on the knowledge and behavior of Chinese citizens, and explore the possibility of focused influence mechanism on the information media where the study is based on internet survey data from 1,373 people in China using an econometric model and concludes that the existence of COVID-19 cases in the community has had a significant positive effect on people's knowledge and behavior of food safety.

Meanwhile, similar research with a national scope has also been carried out, as conducted by (Nasution et al., 2020) which examine the impact of the Covid-19 pandemic on the Indonesian economy with a quantitative descriptive approach with secondary data, conclude that the impact of the COVID-19 pandemic causes low investor sentiment towards the market which in turn leads the market towards a negative trend, so that strategic steps related to fiscal and monetary are needed to provide economic stimulus. (Wiguna et al., 2020) analyze and predict the spread of Covid-19 using the Autoregressive Integrated Moving Average (ARIMA) and the results of predictive analysis show a trend of daily positive cases which tends to increase in the next 14 days from the data used.

\section{METHODS OF RESEARCH}

The methodology used in this research consists of 3 (three) approaches, namely:

To determine the economic conditions in North Kalimantan Province during the Covid19 pandemic, the method used is descriptive statistical analysis. Descriptive statistical analysis is a method commonly used to describe the collected data (Sugiyono, 2016). The data used in this study is secondary data such as the growth rate of gross regional domestic product (PDRB) in 2018 to 2020 in the third quarter, sourced from the Central Bureau of Statistics of North Kalimantan Province.

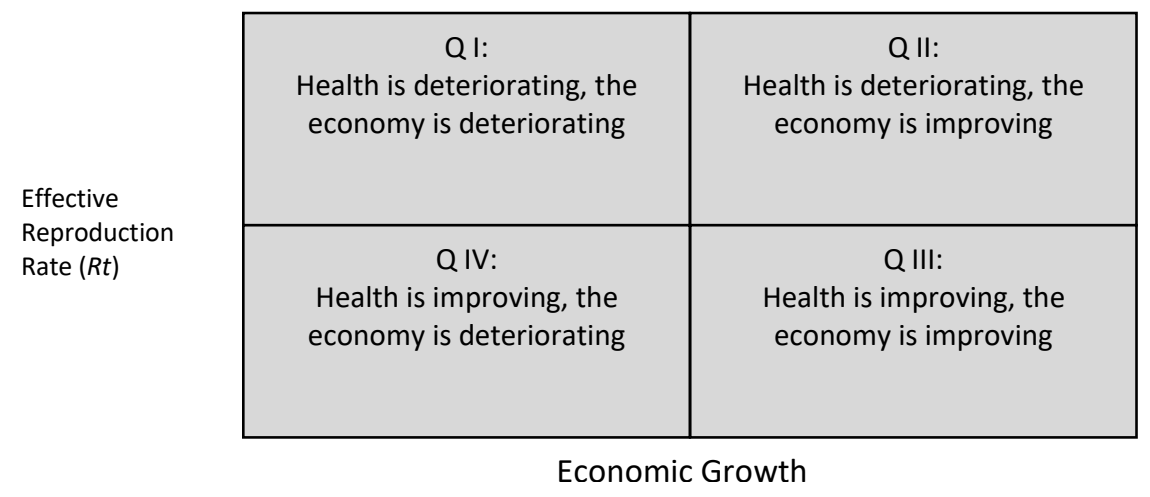

Figure 1 - Quadrant of Health and Economic Condition in North Kalimantan Province

To determine the state of health and economy using 2 (two) indicators, namely the Effective Reproduction Rate (Rt) and the economic growth rate of North Kalimantan Province which is divided into 4 (four) quadrants, where quadrant I describes a deteriorating health condition and a deteriorating economy, quadrant II indicates the health is deteriorating but the economy is improving, quadrant III shows that health is improving in and the economy is improving and quadrant IV is in improving health but the economy is deteriorating. This method is a modification of Damuri et al., (2020) measuring the health condition and national economy during the PSBB period by using 2 (two) indicators, namely the health indicator (Covid-19 intensity) and the economic indicator seen from human movement using Facebook range map data. In this analysis, East Kalimantan, South Kalimantan, West Kalimantan and 
Central Kalimantan provinces are used as a comparison of regional health and economic conditions. The data used in this section are the Effective Reproduction Rate (Rt) and the growth rate of the North Kalimantan province's gross regional domestic product (PDRB) in the second and third quarters of 2020.

The Fuzzy C-Means (FCM) method assisted by MATLAB GUI is used to determine the affected sectors which are then clustered into 3 (three) clusters, namely cluster 1 is the sector with the highest (bad) impact, cluster 2 is a sector with moderate impact and cluster 3 is a sector with low impact. The data used is the distribution of gross regional domestic product GRDP for all sectors / business fields consisting of 17 sectors in the third quarter of 2020.

The FCM algorithm is as follows (Kemala, Astuti, \& Maharani, 2019):

- Input data that will be in the cluster is in the form of a matrix $X$ measuring $n \times m$, where $n=$ the number of data samples and $m=$ the number of variables for each data. $x_{i j}=$ element in the matrix from the sample data $-i(i=1,2,3, \ldots, n)$, the variable $(j=1,2,3, \ldots, m)$.

$$
X_{n \times m}=\left[\begin{array}{ccc}
x_{11} & \cdots & x_{1 m} \\
\vdots & \ddots & \vdots \\
x_{n 1} & \cdots & x_{n m}
\end{array}\right]
$$

Set the number of clusters $(c)$, the rank of the partition matrix $(w)$, maximum iteration (MaksIter), smallest expected error $(\xi))$, initial objective function $\left(P_{0}=0\right)$, initial iteration $((t=1)$.

- Total $c$ must be $\geq 2$;

- Rank $w$ has value> 1,0 ;

Generate a random number $\mu_{i k}$ or degree of membership, where $i=1,2,3, \ldots, n ; ;$ and $k=1,2,3, \ldots, c$; as the elements of the initial partition matrix $U$ of size $n \times c$ where $n=$ the number of data samples and $c=$ the number of clusters.

$$
U_{n \times c}=\left[\begin{array}{cccc}
\mu_{11} & \mu_{12} & \cdots & \mu_{1 c} \\
\mu_{21} & \mu_{22} & \cdots & \mu_{2 c} \\
\vdots & \vdots & \ddots & \vdots \\
\mu_{n 1} & \mu_{n 2} & \cdots & \mu_{n c}
\end{array}\right]
$$

The elements of the initial partition matrix $U_{n \times c}$ must meet the following conditions:

$$
\begin{aligned}
& \mu_{i k}=[0,1] \\
& \sum_{k=1}^{c} \mu_{i k}=1
\end{aligned}
$$

Calculate the center of the cluster $-k$ : $v_{k j}$, with $k=1,2,3, \ldots, c$; and $j=1,2,3, \ldots, m$; where $c=$ number of clusters and $m=$ attribute of each data, using the equation:

$$
V_{c \times m}=\left[\begin{array}{ccc}
v_{11} & \cdots & v_{1 m} \\
\vdots & \ddots & \vdots \\
v_{c 1} & \cdots & v_{c m}
\end{array}\right]
$$




$$
v_{k j}=\frac{\sum_{i=1}^{n}\left(\left(\mu_{i k}\right)^{w} \times x_{i j}\right)}{\sum_{i=1}^{n}\left(\mu_{i k}\right)^{w}}
$$

Where: $v_{k j}$ - the points from the center of each cluster.

Calculate the objective function in iteration $-t$ using the equation:

$$
P_{t}=\sum_{i=1}^{n} \sum_{k=1}^{c}\left(\left[\sum_{j=1}^{m}\left(x_{i j}-v_{k j}\right)^{2}\right]\left(\mu_{i k}\right)^{w}\right)(7)
$$

Calculate the change in the partition matrix using the equation:

$$
\mu_{i k}=\frac{\left[\sum_{j=1}^{m}\left(x_{i j}-v_{k j}\right)^{2}\right]^{\frac{-1}{w-1}}}{\sum_{k=1}^{c}\left[\sum_{j=1}^{m}\left(x_{i j}-v_{k j}\right)^{2}\right]^{\frac{-1}{w-1}}(8)}
$$

Check the stopping condition:

- If ||$P_{t}-P_{t-1}|<\xi|$ atau ( $t>$ MaksIter) then stop;

- If not, then $t=t+1$ and repeat starting from step 4 using updated $\mu_{i k}$.

\section{RESULTS AND DISCUSSION}

Based on data obtained from the North Kalimantan Province Covid-19 Handling Task Force, the first positive cases were found on April 1, 2020, with 2 positive cases of Covid-19. As illustrated in Figure 2, it can be seen that the trend of increasing Covid-19 cases to date is continue to rise, where as of December 6, 2020 there were 1,840 positive cases, 1,150 recovered and 22 cases died.

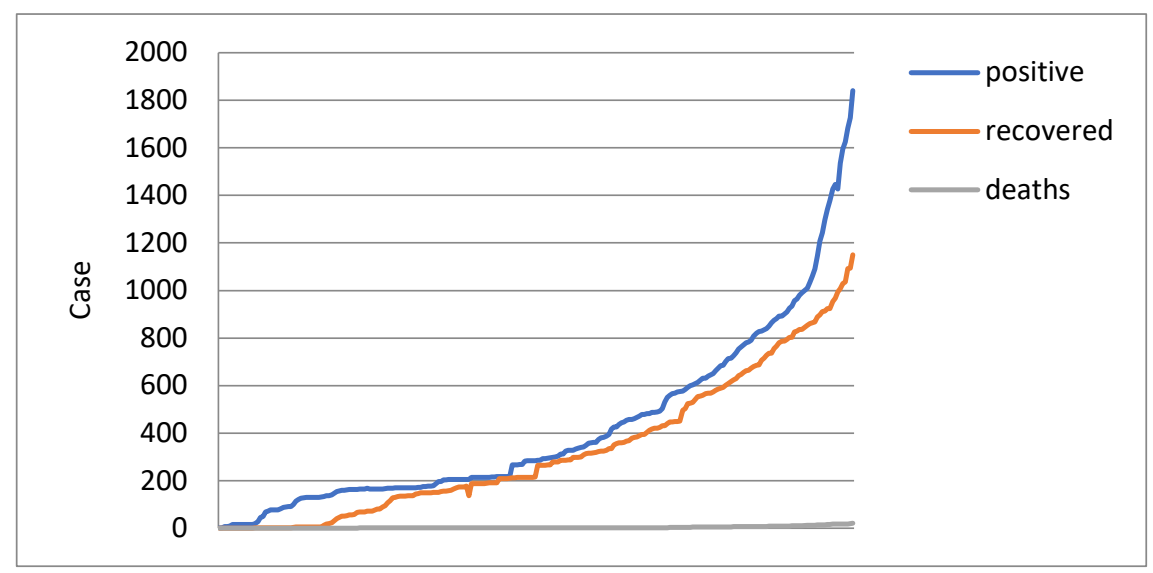

Figure 2 - The Covid-19 Cases in North Kalimantan Province (April - December 2020)

The distribution of Covid-19 cases in North Kalimantan Province is still dominated by 2 (two) regions, namely Tarakan City and Bulungan Regency, while 3 other areas, namely Nunukan Regency, Malinau Regency and Tana Tidung Regency, based on data obtained, the additional cases can is still low. 
Like other regions in Indonesia, several regional government policies in North Kalimantan Province have been issued in the context to prevent the spread of Covid-19 such as Large-Scale Social Restrictions (PSBB) by the City Government of Tarakan. Meanwhile, the North Kalimantan Provincial Government has also issued several policies such as socialization of adaptation to new habits, the formation of a village task force/volunteer against Covid-19, Personal Protective Equipment (PPE) aid for health workers, monthly incentives and death aid for health workers who handle Covid-19, to economic recovery efforts, including social welfare aid for the people of North Kalimantan, direct cash assistance $(B L T)$, and joint business group social assistance. This policy is certainly expected to be able to prevent an increase in Covid-19 cases and also be able to restore the economy of the people affected by Covid-19.

As a result of the Covid-19 pandemic, many countries experienced economic crises, global gross domestic product (GDP) fell by more than 4.9\% in the second quarter of 2020 due to economic disruptions (Padhan and Prabheesh, 2021). Meanwhile, according to Yagi and Managi (2021), the economic damage caused by the Covid-19 pandemic is 1.4 times greater than the 2008 financial crisis. Meanwhile in Indonesia, in the second quarter of 2020, national economic growth slowed down and contracted by minus $5.32 \%$ (Y on $Y$ ), this is the impact of government policies in efforts to prevent the spread of Covid-19 as the results of the study (Aliah, 2020). However, economic growth in the third quarter of 2020 is better than the second quarter of 2020 , which is growing and experiencing an improvement of $5.05 \%(Q$ to Q) (BPS, 2020).

Meanwhile, the economic growth of North Kalimantan Province in the third quarter of 2020 compared to the third quarter of 2019 experiences a contraction of minus $1.46 \%$ as demonstrated in Figure 3.

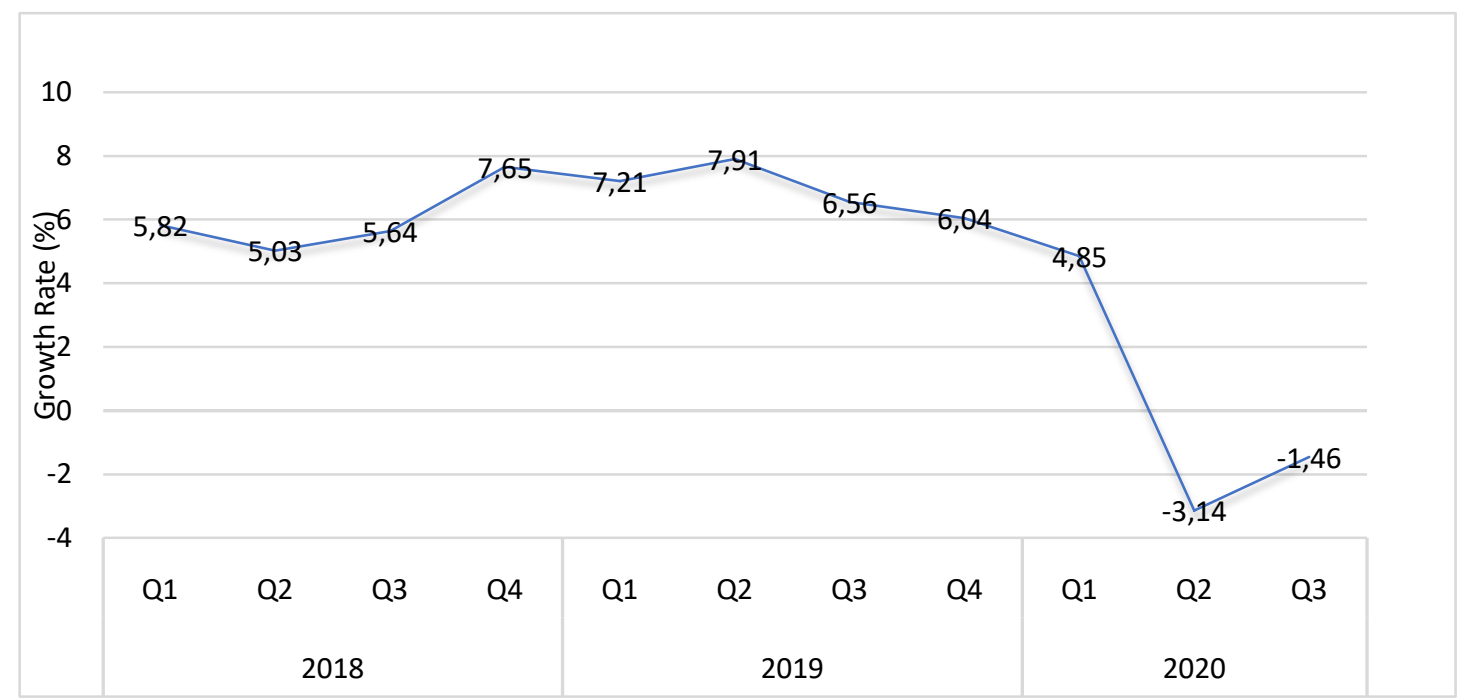

Figure 3 - Growth Rate of Gross Regional Domestic Product of North Kalimantan Province (Y on Y) (Source: BPS Kaltara 2020, processed)

Where there are 4 (four) business fields with the highest contraction, namely the food and drink accommodation business field amounting to minus $10.78 \%$, processing industry business field at minus $7.62 \%$, mining and excavation businesses at minus $6.58 \%$ and transportation and warehousing businesses contracted in the amount of minus $6.9 \%$ ( $\mathrm{Y}$ on $\mathrm{Y})$. The business fields experiencing the highest growth in the third quarter of 2020 (Y on Y) are the electricity and gas procurement business fields by $19.74 \%$, other service business fields at $12.55 \%$, health and social activities business fields by $11.47 \%$, as well as the construction business field of $8.34 \%$.

The application of Large-Scale Social Restrictions in the City of Tarakan has quite an impact on economic activities in other areas such as Bulungan, Malinau, Nunukan and Tana Tidung. In addition, the implementation of social distancing, a system of working and 
studying at home (work from home \& learn from home) are also the cause of the decline in demand, which results in decreased production.

As a whole, the economic growth of North Kalimantan Province has started to improve along with the relaxation of social restrictions and the adaptation of new habits, so that several business sectors/fields have begun to move, such as transportation, accommodation and food and drink which have a fairly wide multiplier effect.

From the expenditure side in the third quarter of 2020 (shown in figure 4), the economic growth experiences contraction by minus $1.46 \%(Y$ on $Y)$. This contraction occurrs due to several business fields experiencing a significant decline in performance, especially foreign imports which are quite significant, namely minus $15.15 \%$, foreign exports by minus $3.96 \%$ and the performance of government consumption expenditures of $3.65 \%$. Meanwhile, the performance of gross fixed capital formation (PMTB) grows positively by $0.49 \%$.

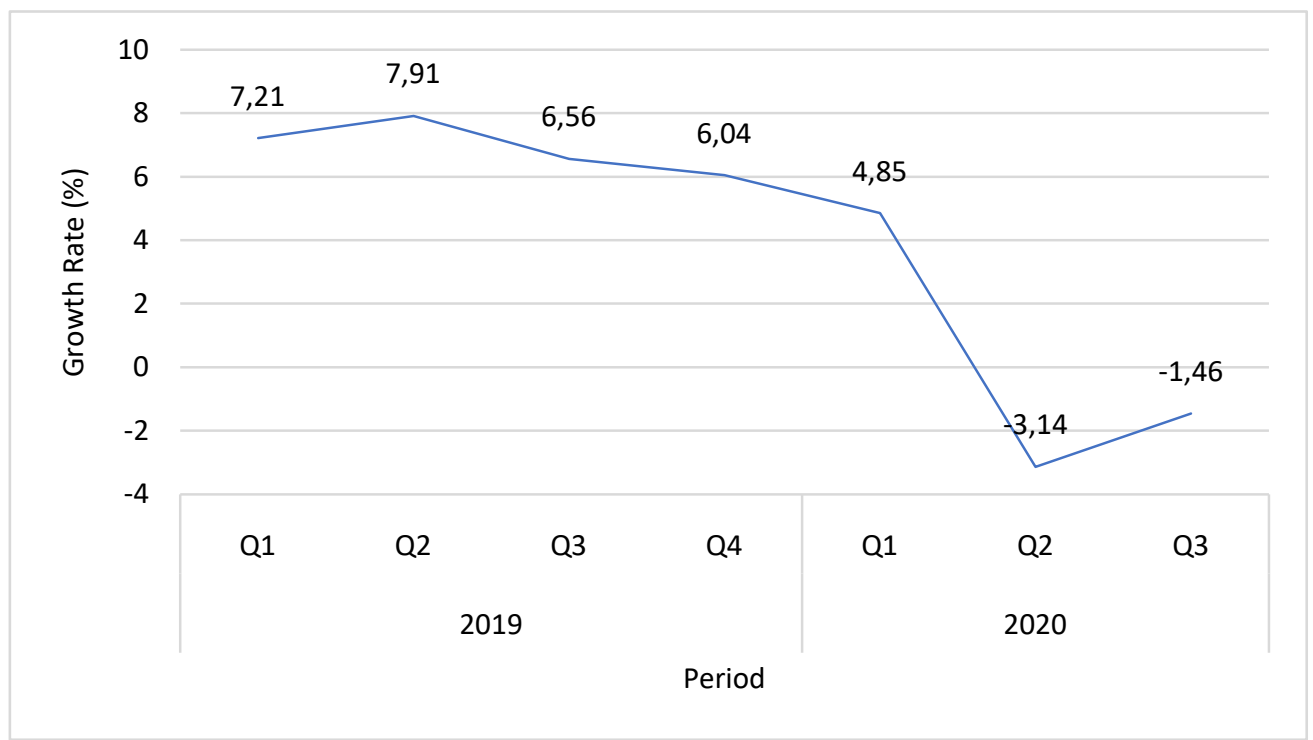

Figure 4 - Gross Regional Domestic Product Growth Rate Based on Expenditure of North Kalimantan Province (Y on Y) (Source: BPS Kaltara 2020, processed)

The largest distribution of total Gross Regional Domestic Product (GRDP) based on expenditures in the third quarter of 2020 ( $Y$ on $Y$ ) is net exports with a share of $44.29 \%$, followed by gross fixed capital formation (PMTB) of $31.30 \%$ and household consumption of $16.10 \%$ (shown in figure 4).

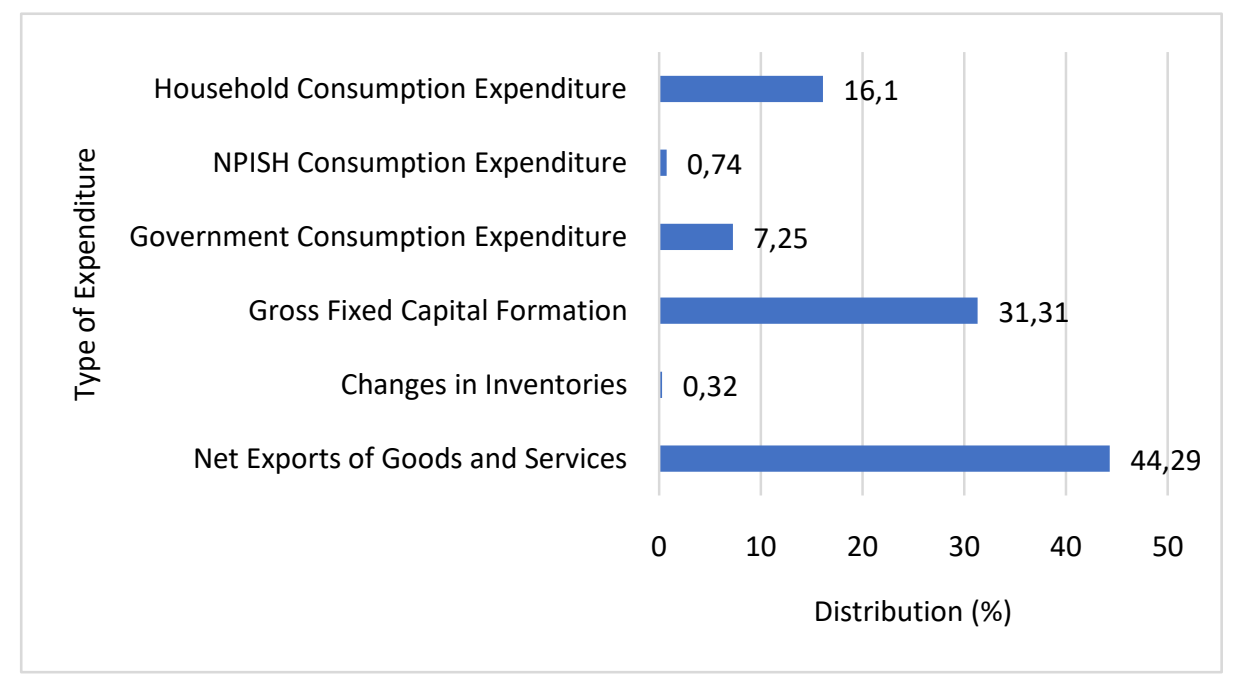

Figure 5 - GRDP Structure according to North Kalimantan Provincial Expenditure in Quarter III of 2020

(Source: BPS Kaltara 2020, processed) 
Economic growth is basically related to the process of increasing the production of goods and services in an economy. An economy is said to experience growth or development if the level of economic activity increases or is higher when compared to the previous year (Maabuat et al., 2016). To see how the state of health and economy of North Kalimantan Province at the time of the Covid-19 pandemic in the second and third quarters of 2020 , measurements are made using 2 (two) indicators, namely the effective reproduction of the Covid-19 case indicated by $\left(R_{t}\right)$ or interpreted as the number of new case births due to 1 infected person entering a population that is fully healthy and potential for illness and an indicator of economic growth. As a benchmark, the measurement is compared to the average economic growth and effective reproduction of Covid-19 cases in Kalimantan, namely East Kalimantan, West Kalimantan, Central Kalimantan and South Kalimantan. Furthermore, the position of each region will be grouped into 4 (four) quadrants.

According to Figure 6, it can be explained that the state of health and economy of North Kalimantan Province based on indicators of economic growth and effective reproduction of the Covid-19 case in the second quarter of 2020 is in the fourth quadrant along with the provinces of West Kalimantan and East Kalimantan, meaning that in this quadrant the value $\left(R_{t}\right)$ of North Kalimantan Province is still below the average, namely 1.0372 or the lowest in Kalimantan, where the average value $\left(R_{t}\right)$ of Kalimantan is 1.3435 and the the highest value $\left(R_{t}\right)$ in the second quarter in 2020 is the province of South Kalimantan at 1.6188 .

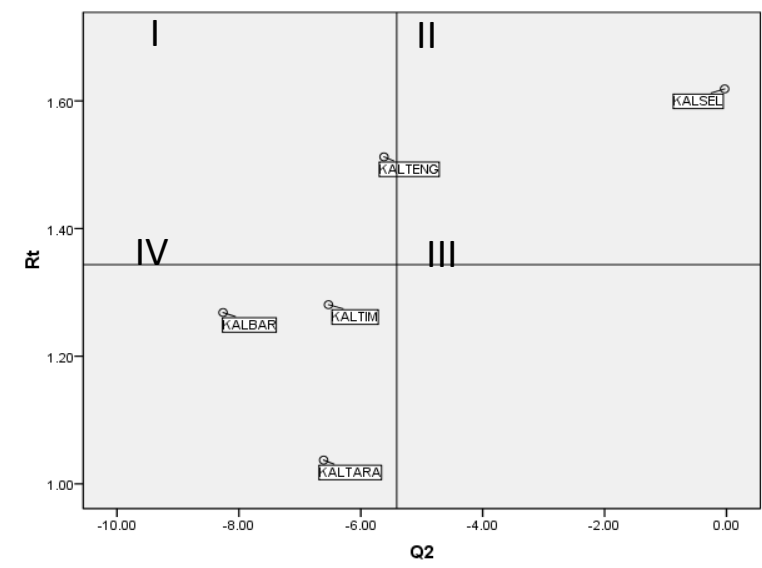

Figure 6 - Health and Economic Condition of North Kalimantan Province in the Second Quarter of 2020

Whereas, the value of economic growth is below the average with an economic growth value of -6.61 , meanwhile the average value of economic growth in Kalimantan is -5.41 , in other words it can be explained that in the second quarter of 2020, the Covid-19 case was only found in North Kalimantan Province around the beginning of April 2020 and the efforts made by the government, both the North Kalimantan Provincial Government and the city governments, were to issue policies to prevent the spread of Covid-19 in the form of closing educational institutions (schools), closing places of worship and shopping centers to PSBB policies. This condition causes the economy in North Kalimantan to experience a contraction.

Based on Figure 7, it can be explained that the position of the economy and effective reproduction $\left(R_{t}\right)$ of North Kalimantan Province in the third quarter of 2020 is in the first quadrant, where the economy of North Kalimantan Province is slightly below the average economic growth in Kalimantan, meaning that in this position the economy of North Kalimantan Province is getting better compared to the second quarter.

This is indicated by positive economic growth, on the side of the effective reproduction of the Covid-19 $\left(R_{t}\right)$ case in the third quarter had experienced increase; this was due to the easing and relaxation of the government which aim to improve economic growth which had experienced a contraction. Therefore, a synergistic policy is needed in an effort to suppress the growth rate of the Covid-19 case, but the economy continues to grow positively. 
The impact of the Covid-19 pandemic on the economy can be seen by sector or business field, this aims to facilitate the identification of the affected sectors until their recovery. Therefore, to see the sectors or business fields affected by the Covid-19 pandemic, this study uses the Fuzzy C-Means algorithm approach using the Matlab GUI software.

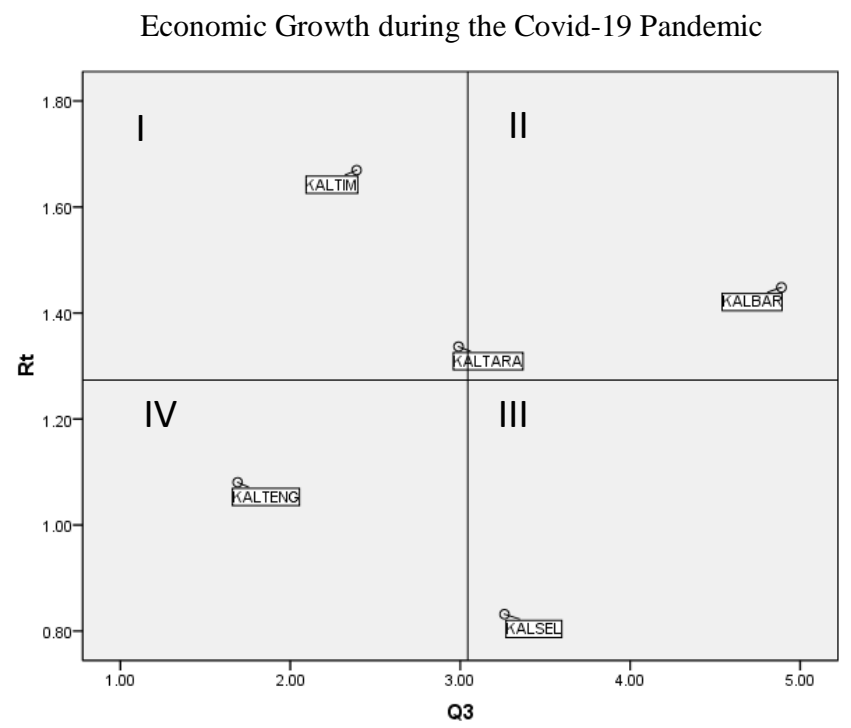

Figure 7 - Position of North Kalimantan Province Based on Economic Growth and Effective Reproduction of the Covid-19 Case $\left(R_{t}\right)$ Third Quarter of 2020

From the calculation, the following results were obtained:

$$
\begin{gathered}
V_{3 \times 2}=\left[\begin{array}{ccc}
-9.8948 & 2.9710 & -6,9238 \\
-2.2311 & 3.1276 & 0.8966 \\
1.7830 & 6.1084 & 7.8914
\end{array}\right] \\
U_{\text {Akhir }}=\left[\begin{array}{lll}
0.0504 & 0.9052 & 0.0445 \\
0.9929 & 0.0054 & 0.0017 \\
0.1464 & 0.7896 & 0.0640 \\
0.1100 & 0.2350 & 0.6550 \\
0.0019 & 0.0103 & 0.9878 \\
0.2191 & 0.3587 & 0.4222 \\
0.0016 & 0.9958 & 0.0026 \\
0.9789 & 0.0163 & 0.0048 \\
0.9131 & 0.0615 & 0.0254 \\
0.0438 & 0.3821 & 0.5742 \\
0.1034 & 0.8387 & 0.0580 \\
0.0430 & 0.6193 & 0.3377 \\
0.0485 & 0.6800 & 0.2715 \\
0.0007 & 0.0036 & 0.9957 \\
0.0025 & 0.9939 & 0.0036 \\
0.0215 & 0.1238 & 0.8548 \\
0.0250 & 0.1198 & 0.8551
\end{array}\right]
\end{gathered}
$$

The value of $V_{3 \times 2}$ in the details above is the center value of the 3 clusters in the last iteration and $U_{\text {Last }}$ is the value on which each category/sector of economic will be placed according to its cluster. The following is a table of cluster results using the Fuzzy C-Means method of the cluster result location from each category/economic field. 
Table 1 - Location of cluster from each data

\begin{tabular}{|c|c|c|c|c|c|c|}
\hline \multirow{2}{*}{ Category / Economic Sector } & \multirow{2}{*}{$\mu_{1 \times 1}$} & \multirow{2}{*}{$\mu_{1 \times 2}$} & \multirow{2}{*}{$\mu_{1 \times 3}$} & \multicolumn{3}{|c|}{ Cluster } \\
\hline & & & & & & 3 \\
\hline A. Agriculture, Forestry and Fisheries & 0.0504 & 0.9052 & 0.0445 & & * & \\
\hline B. Mining and excavation & 0.9929 & 0.0054 & 0.0017 & * & & \\
\hline C. Processing industry & 0.1464 & 0.7896 & 0.0640 & & * & \\
\hline D. Procurement of Electricity and Gas & 0.1100 & 0.2350 & 0.6550 & & & * \\
\hline E. Water Supply, Waste Management, Waste and Recycling & 0.0019 & 0.0103 & 0.9878 & & & * \\
\hline F. Construction & 0.2191 & 0.3587 & 0.4222 & & & * \\
\hline G. Wholesale and Retail Trade; Car and Motorcycle Repair & 0.0016 & 0.9958 & 0.0026 & & * & \\
\hline H. Transportation and Warehousing & 0.9789 & 0.0163 & 0.0048 & * & & \\
\hline I. Provision of Accommodation and Food and Drink & 0.9131 & 0.0615 & 0.0254 & * & & \\
\hline J. Information and Communication & 0.0438 & 0.3821 & 0.5742 & & & * \\
\hline K. Financial Services & 0.1034 & 0.8387 & 0.0580 & & * & \\
\hline L. Real Estate & 0.0430 & 0.6193 & 0.3377 & & * & \\
\hline M,N. Company Services & 0.0485 & 0.6800 & 0.2715 & & * & \\
\hline O. Government Administration, Defense and Mandatory Social Security & 0.0007 & 0.0036 & 0.9957 & & & * \\
\hline P. Educational Services & 0.0025 & 0.9939 & 0.0036 & & * & \\
\hline Q. Health Services and Social Activities & 0.0215 & 0.1238 & 0.8548 & & & * \\
\hline R, S,T,U. Other Services & 0.0250 & 0.1198 & 0.8551 & & & \\
\hline
\end{tabular}

Source: Processed Data (2020).

Based on Table 1, the total results of each data in each cluster can be obtained as follows:

Table 2 - Total 3 Clusters Based on Category/Business Field

\begin{tabular}{llll}
\hline No. & Data & Cluster & Total \\
\hline 1 & B,H,I & 1 & 3 \\
2 & A,C,G,K,L,(M,N),P & 2 & 7 \\
3 & $\mathrm{D}, \mathrm{E}, \mathrm{F}, \mathrm{J}, \mathrm{O}, \mathrm{Q},(\mathrm{R}, \mathrm{S}, \mathrm{T}, \mathrm{U})$ & 3 & 7 \\
\hline
\end{tabular}

From Table 1 and Table 2 it can be explained that cluster 1 is the economic sector/business fields which is the most affected with the high category due to the Covid-19 pandemic, while cluster 2 is the economic sector which is affected in the medium category, and cluster 3 is the economic sector which is not affected.

The following is a categorization table based on the levels:

Table 3 - Categorization Table Based on Level and Center Average Value of Each Cluster

\begin{tabular}{|c|c|c|c|c|c|}
\hline \multirow{2}{*}{ Cluster } & \multirow{2}{*}{ Category / Economic Sector } & \multirow{2}{*}{ Cluster } & \multicolumn{3}{|c|}{ Average Score of Each Cluster } \\
\hline & & & \multicolumn{3}{|c|}{ Variable } \\
\hline 1 & $\mathrm{~B}, \mathrm{H}, \mathrm{I}$ & High & -9.8948 & 2.9710 & -6.9238 \\
\hline 2 & $A, C, G, K, L,(M, N), P$ & Medium & -2.2311 & 3.1276 & 0.8966 \\
\hline 3 & $\mathrm{D}, \mathrm{E}, \mathrm{F}, \mathrm{J}, \mathrm{O}, \mathrm{Q},(\mathrm{R}, \mathrm{S}, \mathrm{T}, \mathrm{U})$ & Low (not affected & 1.7830 & 6.1084 & 7.8914 \\
\hline
\end{tabular}

Source: Processed Data (2020).

Based on the calculation, economic sectors or business fields which are included in cluster 1 (one) and the most affected by the Covid-19 pandemic are mining and excavation, transportation and warehousing as well as food and drink accommodation providers. This result is in line with data from BPS North Kalimantan Province, (2020) which shows that growth for the three business fields in the second quarter experienced a fairly high contraction. According to Vivoda (2020), the Covid-19 pandemic has affected the mining industry, following the implementation of a lockdown which resulted the decrease in demand.

Globally, the transportation sector is one of the most affected sectors which of course has an impact on tourism, according to Škare et al., (2021). The pandemic crisis has had a long-term negative effect on the tourism industry and the economy. Meanwhile, the results of the study by Cui et. al. (2021) shows that the shock of the Covid-19 pandemic has disrupted the transportation sector in China, where on the supply side an increase in protection costs certainly reduces the efficiency and on the demand side there has been a decline. If you look at the structure of the PDRB of North Kalimantan Province so far, the mining sector is the 
sector that provides the largest contribution with a range of $25-26 \%$, but during the crisis time like now it is time for the North Kalimantan Provincial Government to strengthen other sectors that are more resistant to crises such as agriculture, forestry and fisheries. Thus, policy intervention is needed so that these three business sectors/fields can grow positively after the pandemic, and likewise with other business sectors/fields that require policies to maintain economic stability.

In addition to the business sector/field in cluster 1, what needs to be paid attention by the government in order to maintain regional economic stability is in cluster 2 , where the agricultural, forestry and fishery business sectors/fields, as well as the processing industry business fields are 2 of the 7 business fields affected in medium category. Particularly in the agricultural, forestry and fishery business sectors/fields, the government policy intervention in these sectors must be further increased, considering that based on our nation's experience in facing the global crisis, the agricultural sector is a very resilient sector. This is in line with the results of the study by Adriansyah et. al. (2016) which states that development policies in the agricultural sector are able to make a significant contribution to the regional economy (gross regional domestic product). Meanwhile, during the Covid-19 pandemic, the agricultural sector at the national level grew positively during the pandemic (BPS, 2020).

The Covid-19 pandemic is certainly difficult to predict when it will end, especially in North Kalimantan Province, therefore what can be done is to try to minimize the growth rate of the Covid-19 case so that social life can continue and the economy can grow positively. Synergy between all parties, the government, the private sector and even the community is needed, where the role of each agency or institution in carrying out all policies for overcoming and recovering the economy due to the Covid-19 pandemic must also be in line.

\section{CONCLUSION}

Based on the results of the calculations and analysis, it can be concluded that several things related to the impact of the Covid-19 pandemic on the economy in North Kalimantan Province, are as follows:

- The economic growth of North Kalimantan Province in the second quarter experiences a contraction of up to $-3.14 \%$, but in the third quarter it gets better even though it still grows minus at $-1.46 \%$;

- The state of the economy of North Kalimantan Province in the second quarter of 2020 based on calculations with the indicator of the effective reproduction rate $\left(R_{t}\right)$ and the economic growth rate of North Kalimantan Province is in the fourth quadrant, which means that the number of positive cases of Covid-19 is still low but the economy is also low due to policy to prevent the spread of Covid-19, namely PSBB. Whereas in the third quarter of 2020, North Kalimantan Province was in the first quadrant, which means that economic growth was still below the average economic growth in Kalimantan, but the effective reproduction rate $\left(R_{t}\right)$ increased, where the increase in positive cases of Covid-19 was due to the relaxation from the government;

- There are 3 (three) business sectors/fields which are categorized as highly impacted sectors, namely mining and excavation, transportation and warehousing, as well as the accommodation provider of food and drink.

\section{ACKNOWLEDGEMENTS}

Researchers would like to thank the Regional Development Planning Agency and the Research and Development Agency of the North Kalimantan Province for providing support in the form of grant in this research.

\section{REFERENCES}

1. Adrianus Maabuat, Katiandagho, T. M., \& Laoh, O. E. H. (2016). Pemetaan Wilayah Berdasarkan Pertumbuhan Ekonomi Dan Persentase Penduduk Miskin Kabupaten/Kota 
Di Provinsi Sulawesi Utara, 12, 87-94.

2. Adriansyah, D., Setiawan, B., Hanani, N., Syafrial. (2016). The Impact of Capital Expenditure of Agricultural Sector on Economic Performance: Case in North Kalimantan Province, Indonesia. Russian Journal of Agriculture and Socio-Economic Sciences 12(60), December 2016. https://doi.org/10.18551/rjoas.2016-12.03

3. Akbulaev, N., Mammadov, I., \& Aliyev, V. (2020). Economic Impact of Covid-19. SYLWAN, 165(5).

4. Aliah, N. (2020). The Impact of Covid 19 on National Economic Growth. International Proceeding of Law \& Economic, IPLE 2020, 62-68. https://doi.org/10.31305/rrijm.2020.v05.i10.026

5. Badan Pusat Statistik Provinsi Kalimantan Utara. (2020). Berita Resmi Statistik. Bps.Go.Id.

6. BPS. (2020). Laju Pertumbuhan PDB Seris 2010 (persen), 2020. https://www.bps.go.id/indicator/11/104/1/-seri-2010-laju-pertumbuhan-pdb-seri2010.html. Accessed at 05 December 2021

7. Brahmbhatt, M., \& Dutta, A. (2008). On SARS Type Economic Effects during Infectious Disease Outbreaks. World Bank, Policy Research Working Paper, WPS4466(January), 1-28. https://doi.org/10.1596/1813-9450-4466

8. Cui, C., He, L., Liu, Y., Zheng, Y., Wei, W., Yang, B., and Zhou, M. (2021). The Impacts of COVID-19 Pandemic on China's Transport Sectors Based on The CGE Model Coupled with a Decomposition Analysis Approach. Transport Policy. https://doi.org/10.1016/j.tranpol.2021.01.017

9. Damuri, Y. R., Ekonomi, K. D., Aswicahyono, H., Senior, P., Ekonomi, D., Ayu, D., ... Ekonomi, D. (2020). Evaluasi Kegiatan Ekonomi dan Intensitas Penyebaran COVID-19 di Masa New- Normal : Tinjauan atas Beberapa Indikator Cepat [ Pembaruan Data 29 Juni 2020 ]. Centre For Strategic And International Studies, 1-8. Retrieved from https://www.csis.or.id/publications/evaluasi-kegiatan-ekonomi-dan-intensitaspenyebaran-covid-19-di-masa-new-normal-tinjauan-atas-beberapa-indikator-cepat

10. Damuri, Y. R., \& Hirawan, F. B. (2020). Mengukur Dampak COVID-19 pada Pertumbuhan Ekonomi dan Perdagangan Indonesia 2020. CSIS Commentaries DMRU015, (March), 1-8.

11. Kemala, R. F., Astuti, I. F., \& Maharani, S. (2019). Penerapan Metode Fuzzy C-Means Pada Aplikasi Simulasi TOEFL (Test Of English As A Foreign Language) Berbasis Web (Studi Kasus: Fakultas MIPA Universitas Mulawarman). Informatika Mulawarman : Jurnal Ilmiah IImu Komputer, 14(1), 17. https://doi.org/10.30872/jim.v14i1.1954

12. Keogh-Brown, M. R., Jensen, H. T., Edmunds, W. J., \& Smith, R. D. (2020). The impact of Covid-19, associated behaviours and policies on the UK economy: A computable general equilibrium model. SSM - Population Health, 12, 100651. https://doi.org/10.1016/j.ssmph.2020.100651

13. Kumar, P., Singh, S. S., Pandey, A. K., Singh, R. K., Srivastava, P. K., Kumar, M., ... Drews, M. (2021). Multi-level impacts of the COVID-19 lockdown on agricultural systems in India: The case of Uttar Pradesh. Agricultural Systems, 187(September 2020), 103027. https://doi.org/10.1016/j.agsy.2020.103027

14. LIN, B. xi, \& ZHANG, Y. Y. (2020). Impact of the COVID-19 pandemic on agricultural exports. Journal of Integrative Agriculture, 19(12), 2937-2945. https://doi.org/10.1016/S2095-3119(20)63430-X

15. LUO, R. fu, LIU, C. fang, GAO, J. jing, WANG, T. yi, ZHI, H. yong, SHI, P. fei, \& HUANG, J. kun. (2020). Impacts of the COVID-19 pandemic on rural poverty and policy responses in China. Journal of Integrative Agriculture, 19(12), 2946-2964. https://doi.org/10.1016/S2095-3119(20)63426-8

16. MIN, S., XIANG, C., \& ZHANG, X. heng. (2020). Impacts of the COVID-19 pandemic on consumers' food safety knowledge and behavior in China. Journal of Integrative Agriculture, 19(12), 2926-2936. https://doi.org/10.1016/S2095-3119(20)63388-3

17. Nasution, D. A. D., Erlina, \& Muda, I. (2020). Aditia, 2020. Jurnal Benefita, 5(2), 212-224. 18. Padhan, R., \& Prabheesh, K.P. (2021). The Economics of COVID-19 Pandemic: A 
Survey. Economic Analysis and Policy. https://doi.org/10.1016/j.eap.2021.02.012

19. Putra, D. A., 2020. Sri Mulyani: Dampak Akibat Corona Lebih Kompleks Dibandingkan Krisis 2008 \& 1998. https://www.merdeka.com/uang/sri-mulyani-dampak-ekonomi-akibatcorona-lebih-kompleks-dibanding-krisis-2008-1998.html. Diakses Desember 2020

20. Sakri, D. (2020). Menakar Dampak Pandemi COVID-19 terhadap Perekonomian Daerah. CSIS Commentaries DMRU-088-ID, 1-10.

21. Satgas Penanganan Covid-19. (2021). Peta Sebaran Covid-19. https://covid19.go.id/peta-sebaran-covid19. Accessed at 30 January 2021

22. Shrestha, N., Shad, M. Y., Ulvi, O., Khan, M. H., Karamehic-Muratovic, A., Nguyen, U. S. D. T., ... Haque, U. (2020). The impact of COVID-19 on globalization. One Health, 11, 100180. https://doi.org/10.1016/j.onehlt.2020.100180

23. Sikder, M., Zhang, W., \& Ahmod, U. (2020). The Consequential Impact of the Covid-19 Pandemic on Global Emerging Economy. American Journal of Economics, 2020(6), 325331. https://doi.org/10.5923/j.economics.20201006.02

24. Škare, M., Soriano, D. R., \& Porada-Rochoń, M. (2021). Impact of COVID-19 on the travel and tourism industry. Technological Forecasting and Social Change, 163(April 2020). https://doi.org/10.1016/j.techfore.2020.120469

25. Sugiyono, P. D. metode penelitian kuantitatif, kualitatif,dan R\&D, Alfabeta, cv. (2016).

26. WHO. (2021). WHO Coronavirus (COVID-19) Dashboard. https://covid19.who.int/. Accessed at 30 January 2021

27. Wiguna, H., Nugraha, Y., Rizka R, F., Andika, A., Kanggrawan, J. I., \& Suherman, A. L. (2020). Kebijakan Berbasis Data: Analisis dan Prediksi Penyebaran COVID-19 di Jakarta dengan Metode Autoregressive Integrated Moving Average (ARIMA). Jurnal Sistem Cerdas, 3(2), 74-83. https://doi.org/10.37396/jsc.v3i2.76

28. Vivoda, V., (2020). Implications of COVID-19 on the Global Mining Sector. Aspects in Mining \& Mineral Science. http://dx.doi.org/10.31031/AMMS.2020.04.000600

29. Yagi, M., \& Managi, S. (2021). Global Supply Constraints from The 2008 and COVID-19 Crises. Economic Analysis and Policy. https://doi.org/10.1016/j.eap.2021.01.008 